\title{
The impact of small ruminants breeding in the operation of oasian agricultural farms in Algeria
}

\author{
L. Merrouchi ${ }^{1,2 *}$, B. Bouammar ${ }^{2}$, K. Fantazi $^{1}$, L. Aouidane ${ }^{3}$
}

\begin{abstract}
1*NationalInstitute of Agronomic Research of Algeria. 02, Av of brothers Ouddak, Pb 200 Hassen-Badi, ElHarrach-Alger-Algeria; ${ }^{2}$ Research Laboratory on Date Palm, KasdiMerbah University, Algeria; ${ }^{3}$ Department of Agricultural Sciences, AbbèsLaghrourUniversity, Algeria

*Corresponding author email: 1merrouchi@yahoo.fr
\end{abstract}

Journal of Livestock Science (ISSN online 2277-6214) 12: 147-154

Received on 03/02/21; Accepted on 30/3/21; Published on 21/4/21

doi. 10.33259/JLivestSci.2021.147-154

\begin{abstract}
This work focuses on the study of the impact of small ruminantsbreeding in oasis agriculture in the Oued-Righvalley in south-eastern Algeria. Fifty (50) farms maintaining livestock were surveyed using a questionnaire. A principal component analysis (ACP) was performed to determine the typology of the farms studied, using structural and operational variables. Based on ten (10) variables including three qualitative (type of exploitation according to status, prophylaxis and coverage of the animal by food) and seven (07) quantitative (age, area of farms, forage area, organic matter used, organic matter purchased, number of goat heads, number of sheep heads), three types of farms were identified. Type 1 comprises 33 farms (66\%), with an area of 0.5 to 2 hectares and an average of 5.6 heads of animals per farm. Type 2 comprises seven farms (14\%), with an area of 2.5 to 19 hectares and an average of four heads of animals per farm. Type 3 comprises 10 farms (20\%), with an area of 5.2 to 19 hectares and an average of seven animals per farm. The study showed that the farms studied are impacted by the lack of organic matter from their livestock, used in the amendment of their crops, due to the regression in the number of livestock and the narrowness of livestock areas.
\end{abstract}

Keywords: Livestock; Livestock production system; organic matter; oasis; Oued-righ; Algeria. 


\section{Introduction}

The contribution of livestock to the sustainability of agricultural production systems is no less. It ensures the diversification of the income resources of farms and allows for more diversity in the crop rotations, while maintaining soil fertility through the return of manure to the cultivated plots, a crucial element in maintaining the sustainability of the activities agricultural (Srairi et al., 2018). In oasis environments, the agriculture-livestock association is a very common characteristic. It makes it possible to value scarce resources such as arable land and water resources (Dollé, 1985). In this association, livestock is the essential component in the agricultural production system. As it ensures production of milk and meat, it also provides manure, guarantor of the soil fertility of the oasis subjected to intensified farming practices (Dolle, 1990). It is, therefore, an essential element of ecological balance in the oasis (Tisserand, 1990). Manure from small lsedentary breeding in oasis is a valuable commodity for maintaining the fertility of the soils on which the date palmsare cultivated in association with other tiered crops such as alfalfa, which provides the bulk of the herd's food ration(Toutain et al., 1990).Thus, the oasis herd represents a standing capital, the savings of the family but also, especially for small ruminants, a source of easily mobilized cash (Dollé, 1990). The Oued-Righ valley, belonging to an oasis ecosystem, is made up of an oasis rosary and characterized by an agriculture based on the cultivation of date palms and underlying crops (arboriculture, fodder, market gardening), and a family breeding of small ruminants (sheep and goats).

In the past, the livestock kept covered the needs of animal products of the valley's farmers. But, with the expansion of the agricultural surface area, in the context of the Accession to Agricultural Land Ownership (APFA), inducing a notable increase in the number of date palms and an increased demand for an organic matter. In addition, the accession of farmers to modern housing that does not take into account their agro-economic needs, have contributed to the regression of livestock and accentuated the deficit in organic matter and other animal products (milk and meat), largely demanded by the valley's farmers.

The deficit of organic matter resulting from the local breeding forced the farmers to fill their needs in this matter by the recourse to the purchase of this product, brought back from the other regions of the country by the means of the truckers who come to stock up on the region. This has created some speculation in the marketing of manure resulting in higher prices.

The objective of this study is to shed light on the state of breeding and its contribution to the operation of oasis farms through a sample of farms practicing breeding.

\section{Materials and Methods}

\section{Presentation of the study site}

The Oued-righ valley is located in the southeast of Algeria in an elongated depression, between the latitude of $32^{\circ} 54$ 'to $39^{\circ} 9^{\prime}$ ' North and the longitude of $05^{\circ} 50$ 'to $05^{\circ} 75^{\prime}$ East. It stretches from south to north, between the village of Goug(Temacine) and the village of Oum-El-thiour (M'ghair) over a length of $160 \mathrm{~km}$ (Dubost, 1991). It is an oasis-type agro-ecological region whose agriculture is based on date palm cultivation estimated at more than three (03) million palm trees occupying an area of more than 36000 hectares (DSA, 2011) and a population nearly 36400 people (RGPH 2008). Other crops (market gardening, fodder and condiments) are practiced under palm trees as well as a family-type breeding, generally intended for self-consumption (Figure 1).

\section{Methodology}

In order to know the impact of small ruminants breeding in the operation of the date palm farms of the Oued-righ valley, fifty (50) farms were surveyed, randomly selected among those practicing breeding. We used a survey guide structured in structure and operating elements. The variables selected are: the age of the farmer, the area of the farm, the area reserved for fodder, the species and the number of heads per species kept, the prophylaxis, the feeding and the use of the material organic or manure. Draft animals are excluded from the study. The survey was conducted among farms in different agricultural sectors existing in the region, namely 'new farms, traditional or old sector farms and private state farms. Principal component analysis was used to establish the farm typology by identifying farm classes along trend lines. The ACP becomes more and more an essentially descriptive statistical method which allows representing, in a graphic form, the maximum of information contained in a data table (Philippeau, 1992). It makes it possible to see more clearly the link between the characteristic variables of the farms with each other and to observe their distributions (Hanafi et al., 2008). The ACP is in fact a multi-varied analysis method whose objective is to reduce the number of variables (Sossou et al., 2013). Another statistical analysis was used which is the correlation matrix (CM) to identify the correlation between the deferential variables and the operation of the farms. These two statistical parameters were made with the STATISTICA 7.1 software (StatSoft1). 


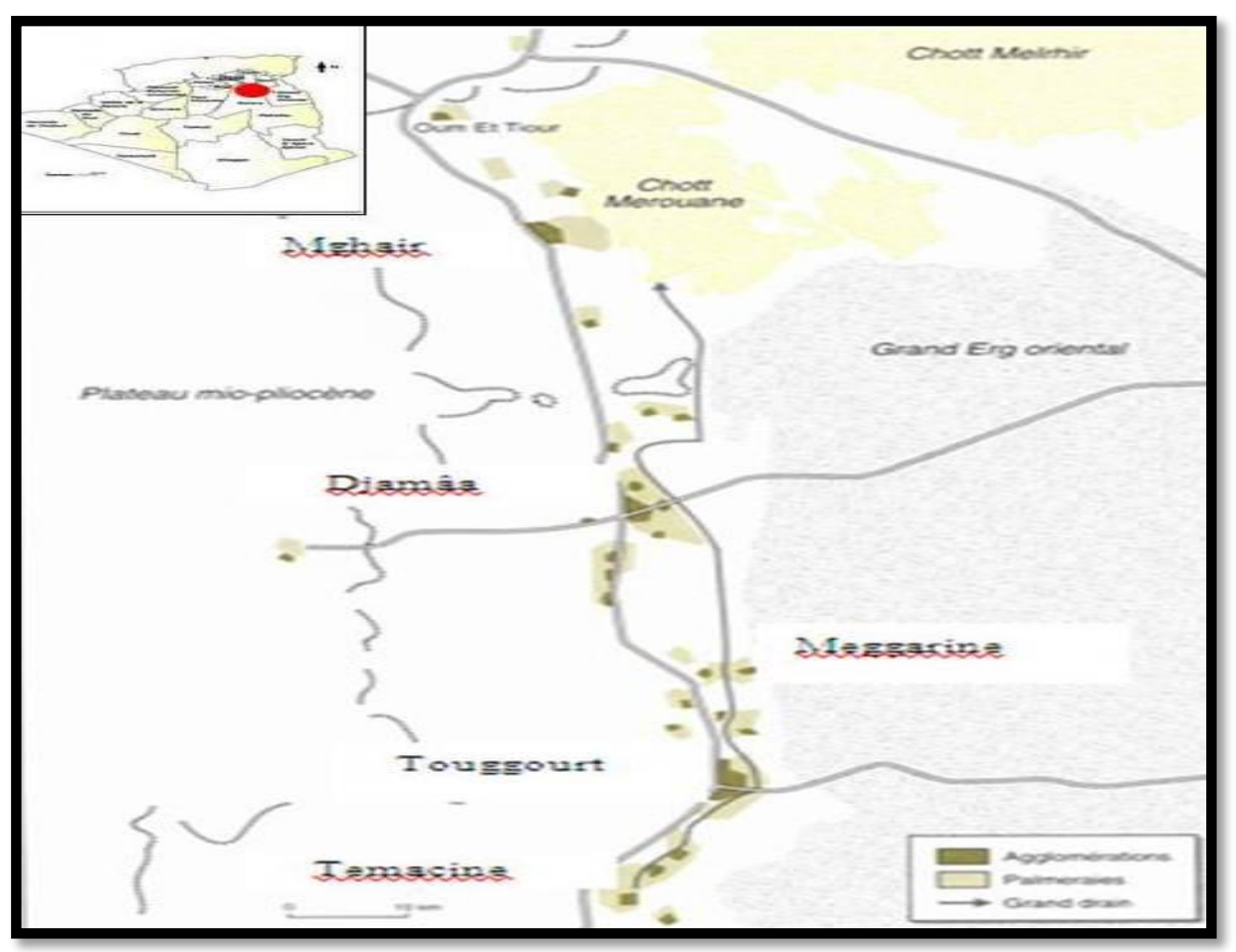

Figure 1.Oued-Righ valley (Côte, 1998), map of Algeria (Kouzmine, 2003)

\section{Results \& Discussion}

\section{Farms characteristics}

The farms surveyed have a total area of 149 hectares (ha), with an average of 3 ha per farm. The smallest area is 0.5 ha and the large area is 19.5 ha of which $66 \%$ of the farms have between 0.5 and 2 ha. The total fodder area is estimated at 11.48 ha, or $7.70 \%$ of the total area, with an average of 0.22 ha of fodder per farm. The number of breedingheads held by the farms surveyed is estimated at 286 heads with an average of 5.72 heads per farm, the smallest herd consists of one head and the largest herd consists of 25 heads. As for the age of the farmers, it is on average 64 years old, of which more than $64 \%$ of the farmers are over 60 , with a minimum age of 38 and a maximum age of 102 (Table 1).

Table 1. Somecharacteristics of the farmssurveyed.

\begin{tabular}{|c|c|c|c|c|c|}
\hline & $\begin{array}{c}\text { Age of } \\
\text { farmers }\end{array}$ & $\begin{array}{c}\text { Total area } \\
\text { (hectare) }\end{array}$ & $\begin{array}{c}\text { Area of fodder } \\
\text { (hectare) }\end{array}$ & $\begin{array}{c}\text { Number of heads } \\
\text { (Sheep and goat) }\end{array}$ & $\begin{array}{c}\text { Quantity of manureused } \\
\text { (quintal) }\end{array}$ \\
\hline Maximum & 102 & 19.5 & 2.5 & 25 & 75 \\
\hline Minimum & 36 & 0.5 & 0 & 1 & 3 \\
\hline Average & 64 & 3 & 0.22 & 5.72 & 20.94 \\
\hline Standard deviation & 13.19 & 3.54 & 0.41 & 4.73 & 16.89 \\
\hline Total & - & 149 & 11.48 & 286 & 1047 \\
\hline
\end{tabular}

Source: Survey data

\section{Typology of farms}

Typologies are above all a method of simplifying reality. They must make it possible to move from a multiplicity of individual cases to a small number of cases (Wey et al., 2007).Any typology proposes to classify farms objectively in such a way that units of the same class are very homogeneous and very heterogeneous in relation to farms of other classes (Jouve et al., 1994).

\section{Study of the variables of analysis}

Before making the typology of farms, we tried to understand and identify the interaction between our variables through CM. According to the correlation matrix of the different variables studied, we have noticedseveral significant correlations, average to weak exist between the different variables (Table 2). 
Table 2. Correlation matrix between the variables studied

\begin{tabular}{|l|l|l|l|l|l|l|l|l|l|l|}
\hline & Age & Type & Area(ha) & Goats & Sheeps & $\begin{array}{l}\text { Forage } \\
\text { area }\end{array}$ & $\begin{array}{l}\text { Feed } \\
\text { coverage }\end{array}$ & $\begin{array}{l}\text { manure } \\
\text { used }\end{array}$ & $\begin{array}{l}\text { Manure } \\
\text { purchased }\end{array}$ & $\begin{array}{l}\text { Animal } \\
\text { care }\end{array}$ \\
\hline Age & 1.00 & & & & & & & & & \\
\hline Type & -0.01 & 1.00 & & & & & & & & \\
\hline Area(ha) & 0.00 & 0.01 & 1.00 & & & & & & & \\
\hline Goats & $\mathbf{- 0 . 1 5}$ & $\mathbf{- 0 . 2 2}$ & 0.18 & 1.00 & & & & & & \\
\hline Sheeps & 0.04 & $\mathbf{- 0 . 1 4}$ & 0.14 & $\mathbf{0 . 3 8}$ & 1.00 & & & & & \\
\hline Forage area & 0.17 & 0.03 & $\mathbf{0 . 3 2}$ & $\mathbf{0 . 4 1}$ & $\mathbf{- 0 . 0 3}$ & 1.00 & & & & \\
\hline Feedcoverage & -0.03 & 0.12 & 0.21 & $\mathbf{- 0 . 1 2}$ & $\mathbf{- 0 . 1 2}$ & $\mathbf{0 . 4 8}$ & 1.00 & & & \\
\hline manureused & $\mathbf{- 0 . 2 4}$ & $\mathbf{0 . 2 5}$ & $\mathbf{0 . 2 2}$ & -0.08 & -0.02 & $\mathbf{0 . 2 2}$ & 0.22 & 1.00 & & \\
\hline manurepurchased & $\mathbf{- 0 . 2 1}$ & $\mathbf{0 . 3 0}$ & $\mathbf{0 . 2 2}$ & -0.26 & -0.19 & $\mathbf{0 . 2 2}$ & 0.26 & $\mathbf{0 . 9 4}$ & 1.00 & \\
\hline Animal care & -0.19 & -0.23 & -0.08 & $\mathbf{0 . 3 1}$ & $\mathbf{0 . 1 3}$ & -0.12 & -0.33 & -0.28 & -0.34 & 1.00 \\
\hline
\end{tabular}

A low correlation was observed between the age of the farmers and the other variables, only a negative correlation with the use and purchase ofmanure, which indicates that older farmers use and buy less manure. Regarding the type of farm (old, private state and APFA) has a negative correlation with the number of goats and sheep and, positive with use and purchase of manure. It deduces that livestock is a popular mode in the old farms than in the state private farms and in the new farms (APFA), however the manure is very used in private farms and APFA than in the old sector.

A mean correlation was found between the number of goats and the number of sheep and the forage area. This indicates that the practice of breeding in the region is mixed where the number of goats and sheep in the herd increases in parallel, while the forage area is positively correlated with the number of goats, so the extension of the forage area is related to the increase in goats this can be explained by the milk production targeted by farmers. Adding to this, the examination of the circle of correlations (ACP) on the main plane (Figure 2b) shows that the variables Goat, Sheep, Area Forage and total area are located in the same direction and in the same way. The direction of these four variables is in opposition to the direction of the farmtype variable. It can be concluded that the number of goat and sheep heads and fodder area is large in old holdings as well as on private state farms and that of new farms, and which increases with the increase in the total area of the farm. While the Animal Care variable is in the opposite direction to the farm type variable, this indicates that the animals on the private state farms and APFA are well cared for relative to animals on older farms.

\section{Classification of farms}

The software provides a principal component analysis of the different variables for group farm classification (Figure 2 (a)). We note a grouping of points (holdings) into three main groups with more or less identical characters that constitute a common type of farm.
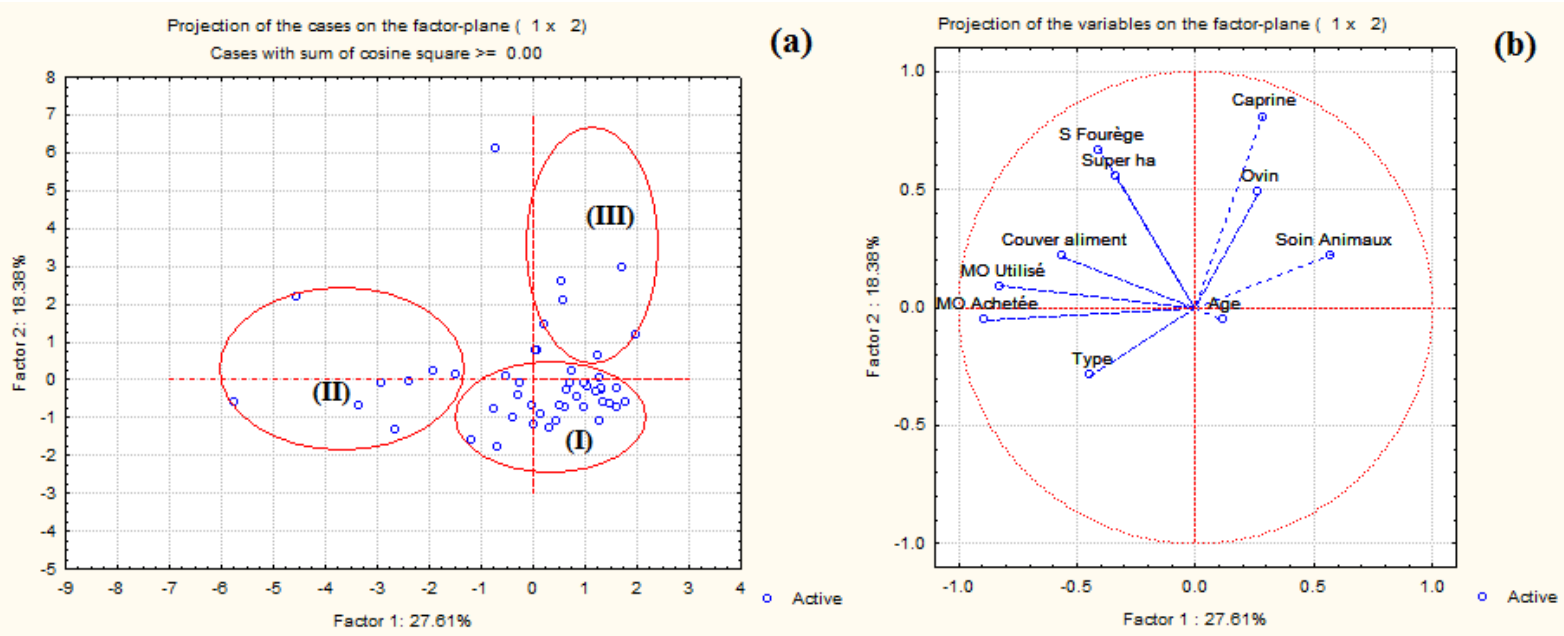

Fig 2. Representation of principal component analysis (a) of individuals \& (b) variables of Oued-Righ holdings. 
The three main groups of farms were characterized by their area (Table 3)

Group1: This group consists of farms ranging in size from 0.5 to two ha (small farms). It concerns 33 farms, or $66 \%$ of the total surveyed. The size of the herd varies between 1 and 25 head between sheep and goats whose head count is estimated at 186 heads. The fodder area is estimated at 4.2 ha and the fodder area / head count is estimated at 0.02 ha per head. The average age of farmers in this group is 66.48 years.

Group2: The area of this group varies between 2.5 and 5 ha (medium farms). The farms concerned by this group are seven,or $14 \%$ of the total surveyed. The herd is composed of 2 to 8 heads and gathers 30 heads in totality. The forage area is estimated at 2.38 ha and the fodder area / head count is 0.08 ha per head. The average age of farmers in this group is 75 years.

Group3: This group has an area varying between 5.2 and 19 ha (large farms) and concerns 10 farms, or $20 \%$ of the total surveyed. The herd varies between 1 and 18 heads and totals 70 heads. The fodder area is estimated at 4.9 ha and the fodder area / head count is 0.07 ha per head. About the average age of farmers in this group is 62 years old.

Table 3. Characteristics by farms group

\begin{tabular}{|c|c|c|c|c|}
\hline Type of farms & Area (ha) & $\begin{array}{c}\text { Number of } \\
\text { farmssurveyed }\end{array}$ & $\begin{array}{c}\text { Herd size (number of } \\
\text { headsheld) }\end{array}$ & $\begin{array}{c}\text { Total number } \\
\text { of heads) }\end{array}$ \\
\hline Small farms & from 0,5 to 2 & 33 & from 01 to 25 & 186 \\
\hline Medium farms & from 2,5 to 5 & 07 & from 02 to 08 & 30 \\
\hline Large farms & from 5,2 to19 & 10 & from 01 to 18 & 70 \\
\hline Total & & 50 & & 286 \\
\hline
\end{tabular}

The flock and its importance

Source: Survey data

The herd owned by the surveyed farms consists mainly of goats and sheep. Nevertheless, the goat is the most preferred species of farmers because it valorizes better the by-products of the farm, proliferates quickly than the sheep and gives milk and meat. While the sheep is, generally, bred to be sacrificed during religious holidays in particular.

The number of herds of surveyed farmsvaries between 01 and 25 per farm, with an average of 5.6 heads. Nevertheless $66 \%$ of the panel have less than five heads per farmOut of a total of 286 heads in all respondents, 93 heads are sheep, or $32.5 \%$, and 193 heads are goats, or $67.5 \%$ of the total population.

In addition, the survey results showed that farmers owning farms with areas of 0.5 to 2 ha, have a herd that varies between 01 and 25 head, farms with areas of 2.5 to 5 ha, have a herd consisting of 02 to 08 heads and finally, farms from 05.5 to 19 ha, have a herd of 01 to 18 heads (Table 3 ). It appears that the size of the livestock is not related to the size of the farm.

\section{Feeding livestock}

Feeding the flock into the study site is bases, primarily, on products of farm, although it is not sufficient. It is generally composed of fodder green (alfalfa, barley green, fodder cabbage and weeds) and coarse food (dates scrap and barley grain). Farmers who do not practice fodder on their farms or the quantity of fodder produced is insufficientdo recourse to the local market to obtain feed for the herd. It is also to stock up grain barley, which is given as a supplement when datesscrap is insufficient.

Thus, more than half of our respondents provide food from their farms to their livestock and use the local market to stock up grain barley and forage in green. This category stated that the farm does not cover the feed requirements of their livestock. The area reserved for fodder by this category is nine ha for a total of 251 head, or 0.03 ha per head.

As for the rest of the respondents, they feed their livestock from the farm only, and the area reserved for fodder is two ha for a head of 35 heads, a ratio of 0.05 ha per head.

As an indication, the cost of the average food ration per head per day, which is composed of a bunch of fodder in green (alfalfa, barley in green) at 50 Algerian Dinars (AD), of a kilogram (kg) of dates scrap at 20 AD maximum and half a $\mathrm{kg}$ of barley grain at $13 \mathrm{AD}$, amounts to $83 \mathrm{AD}$. With this cost, each head would cost almost $30000 \mathrm{AD}$ per year, which is higher than the price of a head of goat or sheep on the market. Nevertheless, the farmer does not do these calculations because his goal is not to earn money but to have some food security.

\section{Fodder production}

The fodder area in Algerian oases, represented by alfalfa and barley crops in green, was estimated by (Djennane, 1990)at 3552 ha on a total irrigated area under palm grove of 61381 ha, an occupation of $0.05 \%$ of fodder, while in Morocco, alfalfa occupies 1/3 of the irrigated area of oasis (Janati, 1990).

In our study site, the most common forage species are alfalfa, followed by barley in green and finally fodder cabbage (Fantazi, 2004). The area reserved for fodder by respondents is 11.48 ha on a total area of 149 ha, or 0.07 ha of fodder on one hectare. The average fodder area per farm is 0.21 ha on an average farm size of 3 ha, which is $0.07 \%$. The ratio of fodder area / head count among the farms of APFA is more significant (0.06 ha / 
head) than in the other categories (0.02 for private owners and 0.04 for owners of the private state) (Table 4). This confirms the orientation of the owners of new farms (APFA) to the market as indicated by (Dubost, 1986).

By type of farm, this ratio is higher for medium farms, it is 0.08 ha / head. Whereas for large farms, the ratio forage area / head number is 0.07 ha. Finally, for small farms whose size varies between 0.5 and 2 ha, the forage area on the number of heads ratio is 0.02 ha (Table 5). We have noted from this study that the area devoted to the forage has increased compared to that which was ten years ago when one hectare of land occupied 0.01 hectare of fodder.If one square meter of fodder produces between 16 and $18 \mathrm{~kg}$ per year (Merrouchi, 2009), 11 ha devoted to fodder by the respondents produce between 1760 and 1980 tons of fodder a year, or almost 5 to 5.5 tons per day. If we divide this quantity by the total number of heads of the farms surveyed, this gives us a ration of 0.01 to 0.02 tons per head per day. This ration seems sufficient, but the production is not intended entirely for livestock. Some poor farmers sell some of the fodder on the market to provide for their families.According to (Fantazi, 2004), the quantities of fodder produced annually for the 1996-2002 periods in the study area were estimated at 7530 tons. These quantities are considered insufficient by the author to only feed the goat herd that existed in the region, causing a deficit of 28 million forage units (FU) and more than 2.5 million $\mathrm{kg}$ of Digestible Nitrogenous Matter (DNM). The lack of food does not allow to have a high performance herd. As (Tisserant, 1990) points out, food is the main obstacle to the development of livestock farming in the oasis.

Amendment by organic matter or manureAs pointed out in the introduction, manure is very important in the amendment of oasis crops, especially the date palms.In our study site, the respondents all use manure in the amendment of their crops. This manure, either it comes from their breeding animals, or it is bought partly from outside. The total quantity used by our respondents is 1047 quintals over a period of two to three years. On average, the amount of manure used, over a period of two to three years, per farm, is 20.94 quintals of which 15.4 Quintals are supplied from the outside, or 73.5\% of the total quantity used per farm.From the foregoing, the quantity of manure used per year and per farm would be 6.98 quintals, rounded up to 7 quintals (assuming the three-year re-amendment period). Knowing that the average surface area of a panel farms is three ha, the quantity of organic matter per year and per hectare would be 2.33 quintals. If the average number of datespalm recommended per hectare is 120 dates palm, the operator's share of organic matter in a dates palm would be 0.019 quintals per year. While the recommended amount is 1.75 quintals per datespalm per year on average depending on climate and soil (Peyron, 2000). Thus, the farms of the surveyed owners have an organic matter deficit of 1.73 quintal per dates palm per year. Nevertheless, the proportion of manure per datespalm per year per farm type is respectively 0.04 quintals, 0.01 and 0.01 for small, medium and large farms. The manure deficit would be 1.71 quintals for small farms and 1.74 quintals for medium and large farms. Knowing that a quintal of manure is paid by the respondents to $2000 \mathrm{AD}$ on average, the expenses generated by the purchase of manure by respondents amount to 512000 AD per year. The expenditure on manure by type of farm is respectively, $7333 \mathrm{AD}$ for small farms, $13714 \mathrm{AD}$ for medium farms and $17400 \mathrm{AD}$ for large farms (Table 6).We have noted from this study that the area devoted to the forage has increased compared to that which was ten years ago when one hectare of land occupied 0.01 hectare of fodder.If one square meter of fodder produces between 16 and $18 \mathrm{~kg}$ per year (Merrouchi, 2009), 11 ha devoted to fodder by the respondents produce between 1760 and 1980 tons of fodder a year, or almost 5 to 5.5 tons per day. If we divide this quantity by the total number of heads of the farms surveyed, this gives us a ration of 0.01 to 0.02 tons per head per day. This ration seems sufficient, but the production is not intended entirely for livestock. Some poor farmers sell some of the fodder on the market to provide for their families. According to (Fantazi, 2004), the quantities of fodder produced annually for the 1996-2002 periods in the study area were estimated at 7530 tons. These quantities are considered insufficient by the author to only feed the goat herd that existed in the region, causing a deficit of 28 million forage units (FU) and more than 2.5 million $\mathrm{kg}$ of Digestible Nitrogenous Matter (DNM). The lack of food does not allow to have a high performance herd. As (Tisserant, 1990) points out, food is the main obstacle to the development of livestock farming in the oasis.

Table 4. forage area per headaccording the legalstatus of holding

\begin{tabular}{|l|l|l|l|l|}
\hline & Total area (ha) & Forage area (ha) & Number of heads & Ratio foragearea /head \\
\hline APFAfarms & 54 & 4.61 & 67 & 0.06 \\
\hline privatesectorfarms & 48.1 & 4.7 & 167 & 0.02 \\
\hline domainprivate statefarms & 46.9 & 2.17 & 52 & 0.04 \\
\hline Total & 149 & 11.48 & 286 & \\
\hline
\end{tabular}


Table 5. Forage area per headaccording the type of farm

\begin{tabular}{|l|c|c|c|c|}
\hline & Total area(ha) & Forage area(ha) & Number of heads & Ratio foragearea per head \\
\hline Small farms & 39 & 4.20 & 186 & 0.02 \\
\hline Medium farms & 27 & 2.38 & 30 & 0.08 \\
\hline Large farms & 83 & 4.90 & 70 & 0.07 \\
\hline Total & 149 & 11.48 & 186 & \\
\hline
\end{tabular}

Source: Survey data

Table 6. Charges generated by the purchase of manure

\begin{tabular}{|l|l|l|l|c|c|c|}
\hline & $\mathrm{n}$ & $\begin{array}{l}\text { Total area } \\
\mathrm{ha})\end{array}$ & $\begin{array}{l}\text { Organic material } \\
\text { used (ql) }\end{array}$ & $\begin{array}{l}\text { Organic material } \\
\text { used /hectare }(\mathrm{ql})\end{array}$ & $\begin{array}{l}\text { Organic material } \\
\text { bought(ql) }\end{array}$ & $\begin{array}{l}\text { Cost of Organic material } \\
\text { per year per farm (AD) }\end{array}$ \\
\hline Small farms & 33 & 39 & 566 & 14.51 & 363.4 & 7300 \\
\hline Medium farms & 07 & 27 & 175 & 6.50 & 145.2 & 13828 \\
\hline Large farms & 10 & 83 & 306 & 3.70 & 261.5 & 17433 \\
\hline Total & 50 & 149 & 1047 & & 770 & \\
\hline
\end{tabular}

\section{Care of the flock}

Source: Survey data

The lack of hygiene added to the precarious stable is a constraint to the performance of the herd. Moreover, emphasized by (Benziouche, 2006), zootechnical parameters in the study area are very bad, particularly those relating to prophylaxis.

On the other hand, the herd is subject to diseases that are treated by our sample, either, by the head of the farm or by one of his family members by traditional methods, or by the private veterinary service or deployed by the State as part of a campaign of screening and vaccination. The survey showed that $80 \%$ of the sample uses the veterinary service to treat their livestock. Those who traditionally care for their livestock represent only $20 \%$ of the panel.It must be said that the agricultural services offer all the facilities for farmers to look after their livestock. Moreover, campaigns of vaccination of the herd are organized periodically.

Those who refuse to present their flock to these services are afraid of the tax authorities and they are not counted in the statistics. The result is that every year these farmers lose at least one head of their herd, either a newborn or an adult.

\section{Conclusion}

Livestock farming in the Oued-Righ Valley can play an important role in the agricultural production system because it is, on the one hand, a source of income certain, and on the other hand, a source of production of several products that can contribute to the food security of the farmer and his family and ensure the sustainability of the farm. On the other hand, livestock in the study area is subject to technical, financial and organizational constraints that prevent it from being effective. The study showed us that the first actors, the farmers, most of whom are old and do not have enough knowledge about the conduct of livestock, which is a handicap to the development of the herd.

In addition, the herd is currently poorly maintained and undernourished, resulting negligible livestock products (milk, meat, manure). Although the area intended for green fodder is interesting, it remains insufficient to cover the existing livestock. In addition, for financial reasons, the farmer directs part of his forage production to the market to provide for his family to the detriment of the animal. Finally, to improve part of the agricultural production and income of the farmer, the maintenance and development of livestock in this area is a necessity. Because, by developing the livestock, we will have contributed to the reduction of the expenses resulting from the purchases of the manure whose needs are in continuous growth, and to increase the income of the farmers by the products of the breeding.

\section{References}

1) Benziouche SE, 2006.Agriculture in the Oued-Righ Valley; Some elements of analysis. Journal of Human Sciences - University of Biskra, No. 10, 19-34.

2) Côte M, 1998. Oases sick of too much water? In cahiers drought, 9(2): 123-130.

3) Djennane A, 1990.Situation report of the southern zones of the Algerian oases. Mediterranean Option, Series A, No. 11, 29-40.

4) Dollé V, 1985. Oasis farming: a judicious association. Livestock farming irrigated under date palms to promote water, a rare resource. Paper presented at the Seminar on "Agriculture and Livestock Relations" DSA-CIRAD - Montpellier - 10-13 September 1985, 70-73. 
5) Dollé V, 1990. Intensive oasis breeding, an important component of the production system. Mediterranean Option, Series A, No. 11, 195-204.

6) Dubost D, 1986.New agricultural perspectives of the Algerian Sahara. Review of the Muslim West and the Mediterranean. V 41, No. 1, 339-356.

7) Dubost D, 1991.Ecology, Planning and Agricultural Development of Algerian Oases. University PhD thesis, 3 volumes, 544.

8) DSA (Agricultural Services Branch), 2011. Agricultural statistics.

9) Fantazi K, 2004.Contribution to the study of genetic polymorphism of goats in Algeria,case of the Oued-Righ Valley (Touggourt). Memory of magister. National School of Agronomy (ENA) El-Harrach-Algiers, $94 \mathrm{p}$.

10) Hanafi S, Zaïri A, Lane P, GrusseP,Ajmi T., 2008.Typology of farms: a starting point to understand the performance of irrigated systems. Proceedings of the third regional workshop of the Sirma project. Water saving in irrigated systems in the Maghreb, Nabeul, Tunisia, 4-7 June 2007. CIRAD, Montpellier, France, symposia-cédérom, $11 \mathrm{p}$.

11) Janati A, 1990. Forage crops in oases. Mediterranean Option, Series A, No. 11, 163-169.

12) Jouve Ph, Dugue M,Mercoiret M., 1994. Support to rural producers, a guide for development agents and group leaders. Ministry of Cooperation Karthala, Paris.ISBN: 2- 86537-520-X, 57-98.

13) Kouzmine Y, 2003. The Algerian Saharan Space, Demographic and Migration Dynamics, University of Franche-Comté,208p.

14) Merrouchi L, 2009. Characterization of an Oasianagro system, evolution and prospects for development. Case of the Oued-Righ Valley.Memory of magister .Kasdi Merbah University of Ouargla, 86p.Philippeau G, 1992. How to interpret the results of a principal component analysis? STAT-ITCF collection, ITCF.Paris. 61p.

15) Peyron G, 2000. Cultivate the date palm. Illustrated training guide, edQuae, $110 \mathrm{p}$.

16) RGPH (General Census of the Population and Habitat of Algeria),2008. General Census of Population.

17) Sossou CH, LebaillyPh, Hinnou CL., 2013. Typology test of farms focused on the financing of agricultural production in Benin. Communication to be presented at the $7^{\text {th }}$ INRA-SFER-CIRAD Social Science Research Days.Angers (Agro Campus West Center of Angers), France. December 12 - 13, 2013, 23 p.

18) Sraïri MT, M'Ghar FA, Mansour S,Alary V., 2018.Diversités et efficience des élevages dans les écosystèmes agraires oasiens : une analyse dans la vallée du Drâa (Maroc). Alternatives rurales (6), Novembre 2018, $13 \mathrm{p}$.

19) Tisserand JL, 1990.Food resources for livestock.Mediterranean Option, Series A, No. 11, 238-241.

20) Toutain G, Dollé V, Ferry M., 1990.Situation of oasis systems in arid regions. Mediterranean Option, Series A, No.11, 07-18.

21) Wey J, Havard M, Djonnewa A, Faikreo J,Takoua S., 2007. Pedagogical module for raising awareness on agricultural advice: Advice on family farming in the cotton zone of Central Africa. Edition Institute of Agricultural Research for Development Cameroon and Cirad of France, 43 p. 